\title{
Zrozumieć emocje - pozorna kontradykcja. Na marginesie książki Andrzeja Dąbrowskiego Źródta, natura i funkcje emocji
}

Justyna TOMCZYK*

\begin{abstract}
Understanding emotions - an apparent contradiction. Comments on Andrzej Dąbrowski's Origins, nature and functions of emotions: This paper offers some polemical comments on Andrzej Dąbrowski's recently published book Origins, nature and functions of emotions. The background for reflection is Leon Petrażycki's theory of emotions (Warszawa 2019). The author aims to evaluate Dąbrowski's presentation of an influential Polish philosopher Leon Petrażycki (1867-1931), considered an important forerunner of the psychosocial theory of law or legal psychologism, who initiated a long-lasting debate on the role and meaning of emotions.
\end{abstract}

\section{KEYWORDS}

emotions; Leon Petrażycki; moral and legal norms; psychic phenomena

* Dr socjologii, adiunkt w Instytucie Filozofii i Socjologii, Uniwersytet Pedagogiczny w Krakowie. E-mail: justynatomczyk1@wp.pl. 
Książka Andrzeja Dąbrowskiego, krakowskiego filozofa i kognitywisty, zatytułowana Źródła, natura i funkcje emocji. Studium teorii impulsji Leona Petrażyckiego w kontekście wspótczesnych badań, ukazała się w 2019 roku nakładem Wydawnictw Uniwersytetu Warszawskiego. Monografia, jak sugeruje podtytuł, to studium teorii impulsji Leona Petrażyckiego, które jest mocno osadzone we współczesnych badaniach naukowych z pogranicza filozofii, etyki, socjologii, psychologii, prawa. Poszerzony kontekst historyczno-analityczny powoduje, iż mamy do czynienia z dyskursem par excellence interdyscyplinarnym. Takie podejście do kwestii emocji umożliwia autorowi wyodrębnienie tych aspektów, które dotychczas nie były brane pod uwagę w należytym stopniu, a które - ze względu na sens czy sedno naukowych dociekań - wydają się fundamentalne. Przede wszystkim dlatego, iż rzetelny opis problematyki wymaga uwzględnienia różnych płaszczyzn badawczych, wyjścia poza jedną jedyną domenę, a więc odstąpienia od radykalnych granic między dyscyplinami wiedzy. Autor włącza do swojego wywodu szereg ustaleń z wielu dziedzin, nawiązując swoisty multinaukowy dialog, którego celem staje się zaniechanie tradycyjnych delimitacji. To przekraczanie granic owocuje ukazaniem perspektyw, które w jednej optyce nie są widoczne, a okazują się niezbędne, by dobrze opisać zjawisko. Dąbrowski, integrując całkiem odrębne podejścia analityczne, oferuje czytelnikowi heterogeniczny ogląd sprawy, który jest pożytecznym efektem owego dialogu. Wzajemne przenikanie teorii oraz metodologii poszczególnych nauk sprzyja powstaniu nowych narzędzi interpretacyjnych, mogących znaleźć zastosowanie w pracach z zakresu identycznej bądź zbliżonej tematyki. Wielopłaszczyznowy charakter dzieła potwierdza osadzenie narracji w złożonym systemie transtekstualnych odniesień i odwołań bibliograficznych - z uznaniem warto zauważyć, że spis bibliograficzny obejmuje unikalną literaturę źródłową oraz trójjęzyczną literaturę sekundarną. Oczywiście balansowanie na pograniczu dyscyplin zawsze jest obarczone dużym ryzykiem, ponieważ naraża autora na zarzut powierzchowności ustaleń lub kakofonii diagnoz czy wniosków. Jednak w przypadku omawianej książki nie znajduje on uzasadnienia, bowiem Dąbrowski bezbłędnie kompiluje poszczególne podejścia, co sprawia, że czytelnik ma możliwość prawidłowego zrozumienia teorii impulsji i zyskania szerszej perspektywy poznawczej.

Recenzowana praca jest zwieńczeniem starań oraz wysiłków autora prowadzonych w celu uzyskania stopnia doktora habilitowanego, będąc równocześnie wskazywana we wniosku habilitacyjnym jako główne osiągnięcie naukowe w drodze do awansu. Fakt ten powoduje, iż pozycja odznacza się typowymi dla rozpraw habilitacyjnych cechami. Przede wszystkim monografię można uznać za dzieło oryginalne oraz nowatorskie, które wnosi wkład w rozwój dotychczasowych ustaleń z zakresu nauk filozoficznych — trudno bowiem wskazać na istnienie wcześniej przeprowadzonych analiz czy rozstrzygnięć w łonie tej problematyki. Chociaż element nowości wydaje się w książce wyraźny 
i eksponowany, to podejmowany temat pozostaje spójny z wcześniej obranym przez autora kierunkiem zainteresowań, dociekań, eksploracji - a więc ściśle koresponduje z jego dotychczas zgromadzonym dorobkiem naukowym, jest w nim obecny od dawna. Jest to dzieło dojrzałe, przemyślane, zakorzenione $\mathrm{w}$ istniejących tezach, potwierdzone poprzedzającymi badaniami. Duże rozeznanie i doświadczenie autora sprawiają, iż mamy do czynienia z opracowaniem wąskospecjalistycznym, zakotwiczonym w gęstej sieci pojęciowej, proceduralnej i faktograficznej - co powoduje, iż staje się ono wymagającą dla czytelnika lekturą. Jednakowoż Dąbrowski należy do raczej wąskiego grona filozofów, którzy nie rezygnując z wybitnie branżowego języka, starają się jednocześnie, by był on zrozumiały dla nie-filozofa.

Najogólniej rzecz ujmując, przedmiotem książki są emocje, co samo w sobie nastręcza wiele trudności, zarówno na poziomie konceptualizacji, jak również operacjonalizacji. Jest to bowiem fenomen na tyle efemeryczny i niestały, że wymyka się jednoznacznemu opisowi bądź generalizacji. Niewątpliwie emocje, uczucia, nastroje stanowią coraz bardziej popularny oraz rozpoznawany w naukach społecznych temat, niemniej nadal brakuje kompleksowych diagnoz czy ekspertyz dotyczących ich znaczenia, oddziaływania, statusu, źródeł. Jeśli już podejmowane są próby eksponowania sfery afektywnej w odniesieniu do sfery kognitywnej lub psychomotorycznej, to najczęściej w psychologii, neurobiologii, psychiatrii (Ekman \& Davidson, 1998; Fonberg, 1979; Reykowski, 1968). Książka Dąbrowskiego jest jedną z nielicznych w polskojęzycznym piśmiennictwie, która przedstawia emocje na tle myśli prawniczej okresu powojennego. Pierwszym i podstawowym azymutem staje się tu teoria impulsji Petrażyckiego, który uchodzi za twórcę doktryny prawnej integrującej teorie prawa z teoriami psychologicznymi. Możliwość tej interferencji wynika z faktu, że psychologia na początku XX wieku zyskuje status samodzielnej nauki empirycznej, co pozwala implementować jej założenia na odrębne pola badawcze. Petrażycki jako zwolennik i czołowy przedstawiciel prawoznawstwa racjonalno-empirycznego staje się pionierem interesujących podejść analitycznych: psychologizmu prawniczego oraz socjologicznej teorii prawa (Kik, 2006; Kojder, 2018). Twierdził on, iż funkcjonowanie prawa bierze swoje źródło w psychice jednostki. W związku z tym przyjęte stanowisko wynika z przekonania o konieczności wsparcia teorii prawa na potwierdzonej doświadczalnie wiedzy o mechanizmach funkcjonowania umysłu (Markowski, 2018: 123). Koncepcje Petrażyckiego w czasach jemu współczesnych nie cieszyły się szczególnym uznaniem, były pomijane, być może nawet lekceważone. Zwłaszcza teoria impulsji mogła uchodzić za niezrozumiałą, gdyż Petrażycki nie w pełni ją dopracował - nie była więc ani popularna, ani rozpropagowana. Poza tym moment historyczny nie sprzyjał zgłębianiu tajników emocji, ponieważ przypadał na czas intensywnych zmagań politycznych i walki z reżimem. Nie był to nurt centralny, stale obecny czy podtrzymywany w dyskursie prawniczym. Tymczasem wydaje się, że warto powrócić do idei 
Petrażyckiego, przywracając im odpowiednie miejsce w poszczególnych dyscyplinach naukowych. Obecnie jego spuścizna naukowa jest dostępna i stosunkowo dobrze znana zainteresowanemu gronu odbiorców (nie tylko w Polsce, lecz także za granicą), jednak liczba publikacji dotyczących teorii impulsji nadal pozostaje niedostateczna. Jak można domniemywać, powodem tego stanu rzeczy jest ciągła dominacja klasycznie rozumianej wykładni prawa, zaś oddziaływanie impulsji na rzeczywistość prawną, a zwłaszcza na prawo intuicyjne, jest nieco marginalizowane. Dobrze się zatem stało, że Dąbrowski zdecydował się sięgnąć po ten „zakurzony” temat, nie tylko dlatego, iż służy to odświeżeniu myśli społecznej, spopularyzowaniu tego wątku czy zainicjowaniu dalszych badań, lecz przede wszystkim dlatego, że teoria impulsji służy zrozumieniu istoty państwa i prawa oraz wyjaśnieniu roli emocji w faktach prawotwórczych.

Recenzowana monografia liczy 267 stron; składa się ze wstępu, pięciu rozdziałów teoretycznych, zakończenia, bibliografii, anglojęzycznego streszczenia, indeksu osobowego. Zarówno objętość, jak i struktura książki są więc dość typowe dla rozpraw habilitacyjnych w dyscyplinie filozofia (co oczywiście nie oznacza, iż nie zdarzają się prace innego rozmiaru i konstrukcji). Wstęp stanowi zgrabnie napisane wprowadzenie do problematyki, które jednocześnie staje się uzasadnieniem dla podjęcia przedkładanej analizy. Dowiadujemy się w nim o motywie przewodnim pracy, jej układzie, kompozycji, randze tematu, konieczności jego dyskutowania. Rozdział pierwszy ma wyraźne nachylenie historyczne i przedstawia kategorię emocji na tle poszczególnych epok: starożytności, średniowiecza, nowożytności, XIX wieku. Zastosowana tu periodyzacja służy przede wszystkim uwypukleniu różnic w postrzeganiu, rozumieniu i systematyzacji emocji, by w efekcie zarysować pole interpretacyjne dla rozważań nad koncepcją petrażycjańską. Opis jest fragmentaryczny i zwięzły, ale wystarczający, by syntetycznie przedstawić problemy związane z badaniem emocji oraz pytania, które stoją u podstaw tych dociekań lub bezpośrednio z nich wynikają. Rekonstruując poglądy starożytnych na temat emocji czy zmysłów, Dąbrowski zaznacza, iż był to wątek obecny, a nawet jaskrawy, w pismach Platona, Arystotelesa, Zenona z Kition, Cycerona, Chryzypa. Chociaż wymienieni myśliciele wskazywali na różne praźródła emocji, to generalnie lokowali je w umyśle i utożsamiali ze zmysłowością jako sposobem poznania. Podkreślając irracjonalizm emocji oraz ich opozycyjność wobec racjonalnej i logicznej natury człowieka, zalecali powściągliwość, ostrożność i dystans. Wieki średnie z jednej strony podtrzymywały przekonania starożytnych, zaś z drugiej były ściśle związane z doktryną chrześcijańską, co powodowało specyficzne postrzeganie oraz ujmowanie afektów. Emocje były elementem świata doczesnego, a więc utrudniały drogę do zbawienia oraz osiągnięcie życia wiecznego — „uczucia nasze, nawet wtedy, gdy są prawe i odpowiadają zasadom Bożym, przynależą do tego życia, a nie do tamtego, którego spodziewamy się na przyszłość" (Augustyn, 1977: 149, cyt. za: Dąbrowski, 2019: 24). Nie oznacza to jednak, 
jak słusznie podkreśla Dąbrowski, iż emocjonalność była traktowana jako siła zagrażająca czy niebezpieczna, jako element zbędny, bowiem pewne emocje (na przykład miłość i radość) oceniano jako pożyteczne, a wręcz nieodzowne, bezwzględnie potrzebne. Dużą partię tego podrozdziału autor poświęcił Tomaszowi z Akwinu - wnikliwie zanalizował opisy emocji w dwóch ważnych i obszernych dziełach Akwinaty (Suma teologiczna; Dysputy problemowe. O zmystowości. O uczuciach), dokonując generalizującego ich oglądu. Fragment ten uznaję za szczególnie potrzebny, bowiem na jego podstawie Dąbrowski określa główne źródło emocji - ruch, stan poruszenia (co zresztą potwierdza etymologia słowa - łac. emovere oznacza „poruszać, porwać, potrząsać”). W świetle nauk Tomasza uczucia są pochodną pożądania oraz zmysłów. Jako siła zmienna i dynamiczna zależą nie tylko od rozumu, lecz także od ciała - to właśnie cielesność i fizjologia warunkują odczuwanie oraz przeżywanie. Tak więc emocje to nie tylko bierne i niezależne od podmiotu doświadczenie, ale również „doznanie czynne”, angażujące, wymagające działania. Dąbrowski, dostrzegając wymiar poruszenia w emocji, pisze: „w najbardziej podstawowej postaci poruszenie to może być wywołane przez daną zmysłową lub fizjologiczno-cielesną, ale w pewnych sytuacjach może to być też wyższy czynnik intelektualny" (Dąbrowski, 2019: 28). Zwraca tym samym uwage, iż interpretacja emocji powinna, paradoksalnie, odnosić się do sfery nie tylko fizjologicznej i behawioralnej, lecz także poznawczej, intelektualnej.

Kolejne podrozdziały dotyczą emocji w filozofii nowożytnej i dziewiętnastowiecznej. Dąbrowski powołuje się na rozważania Descartes'a, Spinozy, Hobbesa - wybór tych nazwisk jest zasadny, gdyż każdy z wymienionych wypracował własną „filozofię afektów”. Właśnie Kartezjusz może być uznawany za prekursora teorii neurofizjologicznych, gdyż udowadniał, że esprits rodzą się w mózgu, a dopiero dzięki nerwom są odczuwane w ciele. Temu twierdzeniu jednak przeczą niektórzy badacze - między innymi portugalski neurolog behawioralny, Antonio Damasio, który neguje sprzeczność między pierwiastkiem emocjonalnym a racjonalnym (Damasio, 2011). Niezależnie od tego, gdzie leży racja, trzeba podkreślić, że myśl kartezjańska była na tyle nośna, że stała się odniesieniem dla Spinozy. Jak trafnie zauważa Dąbrowski, Spinoza czerpał od Kartezjusza, jednocześnie kwestionując jego założenia — zwłaszcza dualizm duszy i ciała, gdyż sam orędował za paralelizmem psychofizycznym. Jeżeli więc stan ciała odpowiada stanowi umysłu, to afekty są fenomenem psychofizycznym - na potwierdzenie tej tezy Dąbrowski przytacza wiele cytatów pochodzących ze spinozjańskiej Etyki. Dużą partię tego podrozdziału zajmuje opis koncepcji emocji Adama Smitha oraz Davida Humea. Ten ostatni wskazywat na różnorodne formy życia emocjonalnego, typizował uczucia (bezpośrednie vs. pośrednie) i impresje (zmysłowe vs. refleksyjne). Dla Hume’a uczucia są główną siłą motywującą, impulsem do działania, zaś rozum jest im poddany — jak pisze Dąbrowski — „sam z siebie nie może bezpośrednio inicjować 
działania, ale nie może także żadnej aktywności hamować. Nie może też przeciwdziałać czemuś, co obdarzone jest mocą sprawczą. Moc taką mają uczucia" (Dąbrowski, 2019: 43). Teza Hume'a o prymacie uczuć nad rozumem zdeterminuje późniejszą myśl Petrażyckiego, więc jej unaocznienie jest newralgiczne dla dalszych rozważań. W części Nowożytność celem autora jest, jak mogę przypuszczać, próba utworzenia holistycznego obrazu teorii emocji w okresie między średniowieczem a XIX wiekiem. Zastosowanie tej klamry temporalnej budzi moje wątpliwości - przede wszystkim dlatego, iż z powodu ogromnej rozpiętości czasowej trudno tutaj o spójną generalizację. Nowożytność - czyli renesans, barok, oświecenie, romantyzm - to wszak kilka niezależnych od siebie epok, które charakteryzują się innym dominującym kierunkiem, prądem, programem, ideologią. Skoro Dąbrowski tak duży akcent położył na sprawozdawczy opis kategorii emocji w historii filozofii, to w mojej ocenie pominięcie tych subtelności (zwłaszcza jeśli chodzi o pierwszą połowę romantyzmu) jest pewnym uproszczeniem. Oczywiście mam świadomość, iż linie czasowe, którymi posiłkuje się autor, są zgodne z tradycyjnym sposobem periodyzacji, jednak w moim przekonaniu w analizach emocji czy emocjonalności warto zauważać i zaznaczać różnice. Zastrzegam jednak, że jest to tylko sugestia, którą autor może podać w wątpliwość, broniąc własnego stanowiska i uzasadniając wybór. Niewykluczone, iż dywagacje o uczuciach w oświeceniowym sentymentalizmie lub w romantyzmie nie wniosłyby nic szczególnego do książki. Można także uznać - zgodnie zresztą z sinusoidą dziejów - iż co druga epoka jest koherentna ideowo i programowo, czerpie z dorobku swojej „przedpoprzedniczki”, więc opisywanie wszystkich po kolei byłoby powielaniem podobnych treści.

XIX stulecie przynosi nowe spojrzenie na sferę afektywną - Dąbrowski podkreśla, iż jest to ważny czas $\mathrm{w}$ dysputach o emocjach, ponieważ dyskurs zmienił swoją orientację z religijnego i metafizycznego, ukierunkowując się na nauki przyrodnicze i matematyczne. Zatem ta część książki wymagała kontaminacji odrębnych, często rozbieżnych, punktów widzenia prezentowanych przez naukowców wywodzących się z odmiennych środowisk i kręgów towarzyskich, reprezentujących różne szkoły, pochodzących z wielu krajów. Autor wykorzystuje tu mnogie źródła i powołuje się na szereg odniesień literaturowych; zręcznie łączy i przeplata wątki psychologiczne z filozoficznymi, uzyskując summa summarum skondensowany, wysycony niezbędnymi szczegółami tekst, który z powodzeniem mógłby funkcjonować jako samodzielny artykuł encyklopedyczny opisujący trajektorię dyskursu emocjonalnego w XIX wieku. Ten podrozdział przeczytałam z dużym zainteresowaniem, być może dlatego, iż ma wyraźne nachylenie psychologiczne i bardzo konkretnie prezentuje znaczenie oraz wielowymiarowość emocji, ich wpływ na procesy poznawcze, zachowanie jednostki. Świetnie, że Dąbrowski wyakcentował perspektywę ewolucyjną Charlesa Darwina (moim zdaniem podłoże socjobiologiczne jest absolutnie kluczowe), a w dalszej kolejności przybliżył klasyczny artykuł What is an emotion? napisany 
w 1884 przez Williama Jamesa, który otworzył dyskusję na temat źródeł oraz następstw pobudzenia emocjonalnego. Oprócz tego Dąbrowski zapoznał czytelnika ze stanowiskami niemieckich filozofów, psychologów, pedagogów, którzy położyli fundament pod współczesną naukę o emocjach — są nimi: Johann Friedrich Herbart, Friedrich Eduard Beneke, Rudolf Hermann Lotze, Wilhelm Wundt. Stanowisko tego ostatniego jest uznawane za konstytutywne w interpretowaniu emocji przez pryzmat cielesności, ale Dąbrowski odsłania jego defekty. Zwraca uwagę, iż Wundtowskie tezy są kontrowersyjne, gdyż nie tylko deprecjonują znaczenie woli w odniesieniu do uczuć, lecz także grupują uczucia i ich pochodne w sposób zawiły, chaotyczny. W dalszej części autor konceptualizuje emocje, sięgając po ustalenia szkockich uczonych: Thomasa Browna, Thomasa Reida, Alexandra Baina (nawiasem mówiąc, Dąbrowski przeinaczył fakt, określając Baina jako „angielskiego filozofa” - ten urodził się i umarł w Aberdeen, skądinąd urokliwym mieście, które jednak znajduje się w Szkocji, a nie w Anglii). Podrozdział zawiera także rekapitulacje poglądów wybranych amerykańskich strukturalistów oraz funkcjonalistów, a jednocześnie inicjuje wątek przewodni książki, który doczeka się pełnej realizacji w następnych odsłonach.

Rozdział drugi nosi finezyjny tytuł: Petrażyckiego uzasadnienie potrzeby badań w zakresie psychologii emocji oraz kwestie metodologiczne - chociaż nie przepadam za zdobną stylistyką tytułów i odwróconym szykiem składniowym, to nie tyle styl zwraca moją uwagę, co zapowiedź bądź obietnica, którą składa tu autor. Otóż ten właśnie tytuł sugeruje, iż czytelnik dowie się o fundamentalnych kwestiach: teoretycznej podstawie badań i konieczności ich podjęcia oraz metodologii, na której te badania powinny się opierać. Rozdział wydaje się zatem węzłowy dla całości koncepcyjnej książki, gdyż jednocześnie odsłania powody, dla których warto było tę książkę napisać. Wywód rozpoczyna się od prezentacji opinii wybranych uczonych na temat przedsięwzięcia naukowego Petrażyckiego, jakim jest polityka prawa. $\mathrm{Na}$ tej podstawie Dąbrowski zakreśla ramy teoretyczne (rozciągnięte pomiędzy prawem, psychologią, biologią, socjologią) psychologicznej teorii prawa wraz z zapleczem metodologicznym, które ją tworzy. Pada tu wiele ważnych wniosków i stwierdzeń, które potwierdzają naczelną petrażycjańską tezę, że zjawiska prawne to w gruncie rzeczy procesy psychiczne. Zgodnie z ustaleniami Petrażyckiego prawo jest swoistą emocją mającą charakter binarny: imperatywny oraz atrybutywny. To założenie, szeroko eksponowane w rękopisach, stanowiło asumpt do powstania psychospołecznej teorii prawa, którą Dąbrowski traktuje jako punkt odniesienia dla podejmowanych rozważań. Przyjmując tę optykę, trzeba udobitnić pierwotność zjawisk prawnych bez względu na typ społeczności czy społeczeństwa, w którym występują. Jak słusznie zaznacza, fenomeny prawne nie są obiektywne czy niezależne od podmiotu, lecz są „czymś, co pierwotnie realnie istnieje w psychice podmiotu jako pewne przeżycie, które następnie jest projektowane na 
zewnątrz" (Dąbrowski, 2019: 64). Tym samym skodyfikowana norma prawna jest wyłącznie quasi-reprezentacją przeżyć prawnych, wypadkową przeżyć własnych i czyichś, więc nie powinna być identyfikowana jako zewnętrzna czy nieświadoma. Trzeba w tym miejscu pochwalić pracę i wysiłki autora, ponieważ rekonstrukcja teorii Petrażyckiego jest zadaniem dość skomplikowanym z co najmniej dwóch powodów. Po pierwsze: niektóre rękopisy uległy zniszczeniu podczas II wojny światowej, a zatem nie ma możliwości pełnej rekonstrukcji zamysłu badawczego. Po drugie, istnieje niespójność i niekonsekwencja w ocenie hipotez i rozstrzygnięć Petrażyckiego, co rodzi liczne problemy w procesie uogólniania czy rozszerzania jego twierdzeń na większe pole naukowe. A nawet jeśli to się uda, to mnożą się trudności, aby wywiedzione wnioski wdrożyć do aktualnych badań. Dąbrowski, zapewne mając tę świadomość, podejmuje się trudnego zadania i mozolnie je realizuje. W ten sposób przygotowuje podatny grunt pod dalszą część książki, która stanowi jej clue.

W rozdziale trzecim intencją autora jest klasyfikacja zjawisk psychologicznych - co samo w sobie wydaje się karkołomne. Niemniej Dąbrowski chce, jak widać, sprostać wyzwaniu i rozpoczyna od rewizji stanowisk filozoficznych na przestrzeni dziejów - idzie utartą wcześniej ścieżką i ponownie sięga do klasycznych dzieł filozoficznych (Platon, Arystoteles, św. Augustyn, Kant) i ich późniejszej recepcji. Poglądy większości wymienionych były już awizowane, więc niniejszy rozdział traktuje jako dopełnienie rozdziału pierwszego. Równocześnie wykorzystanie tego manewru umożliwia płynne przejście do zaprezentowania krytycznego stanowiska Petrażyckiego wobec trójelementowego podziału zjawisk psychologicznych: poznanie - uczucia - wola. Czytelnik, przeczytawszy ten passus, zyskuje rzetelną wiedzę, czym owe elementy są, jakie są ich wyróżniające właściwości, z czego się składają, co jest ich następstwem. Analiza, którą prowadzi tu Dąbrowski, jest staranna, drobiazgowa, kompatybilna wobec literatury przedmiotu, a jednocześnie znacznie poza nią wykracza, rzuca nowe światło na zastane, często archaiczne, interpretacje. Niezwykle ważny moim zdaniem jest fragment, w którym autor odpowiada na pytanie o trafność i użyteczność klasyfikacji Petrażyckiego, sygnalizuje słabości jego podejścia i wątpliwości, jakie na tym tle się rodzą. Dotyczą one jednorodności emocji ze względu na ich pasywno-aktywny charakter, rzekomej bierności poznania i uczuć, hybrydycznego sposobu ich przeżywania. Dąbrowski to odnotowuje i eufemicznie stwierdza: „niewątpliwie podział Petrażyckiego pozostawia niedosyt i może budzić różnego rodzaju zastrzeżenia" (Dąbrowski, 2019: 124). Aczkolwiek, pomimo wielu nieścisłości pojęciowych, nieciągłości terminologicznej oraz uchybień w zakresie formułowania hipotez i wniosków, trzeba uznać tę koncepcję za wiodącą, a właściwie za jedyną uznaną i potencjalnie możliwą do zastosowania. Jak podsumowuje autor: „Petrażyckiego klasyfikację zjawisk psychicznych można by ocenić surowo, a nawet ją odrzucić, gdyby istniała inna, adekwatna, wyczerpująca i powszechnie obowiązująca. Niestety - o ile mi 
wiadomo - klasyfikacji takiej jeszcze nikt nie zaproponował" (Dąbrowski, 2019: 128).

Rozdział czwarty nawiązuje do poprzedniego, a właściwie wprost z niego wynika. Poczynione wcześniej rozważania oraz systematyzacje stanowią preludium do ukazania fenomenu impulsji - koncepcyjnej podstawy tej książki, osi tematycznej, słowa-klucza. To pojęcie, wyeksponowane już w tytule, jest na tyle ważne, że należy je zdefiniować w sposób maksymalnie rygorystyczny i dokładny. Tak też się dzieje. Dąbrowski za Petrażyckim podkreśla powszechności impulsji, opisuje ich znaczenie, rodzaje (przeżycia apulsywne i repulsywne), oddziaływanie, naturę, dynamikę, natężenia, możliwości poznania. Impulsje ujmuje jako część sfery zjawisk psychicznych, które potwierdzają, iż podstawą ludzkich działań są nieświadome bodźce, mogące w pewnym sensie potwierdzać istnienie instynktu czy popędu. Jako paradygmatyczny wzór impulsji Dąbrowski wymienia dwudzielność „apetyt-głód”. Z dużą przyjemnością przeczytałam ten ustęp, bowiem jest interesujący i zastanawiający pod kątem aktywacji mechanizmów fizjologicznych, które nie tylko są skutkiem przebiegu czynności życiowych, lecz także głęboko zakorzeniają się w systemie społeczno-ekonomicznym i w psychologii jednostki (właściwościach osobniczych, reakcjach obronnych, samopoznaniu). Fragment ów podoba mi się też dlatego, iż $\mathrm{w}$ pewnym sensie przypomina prace antropologiczne ukierunkowane na wyjaśnienie prawidłowości jakiegoś zjawiska poprzez odniesienie do najbardziej elementarnych potrzeb, zachowań, doświadczeń (sensorycznych, emocjonalnych, cielesnych) - tego wszystkiego, co składa się na codzienne praktyki oraz wzory kultury. Rdzeniem merytorycznym tegoż rozdziału jest poświęcona impulsom dyskusja prowadzona w kontekście innych badań. Autor przytacza krytyczne uwagi czy komentarze wobec twierdzeń Petrażyckiego formułowane przez filozofów, prawników, psychologów, socjologów, ekonomistów, historyków. Rekapitulacja tych opinii oraz komentarzy stanowi niekwestionowaną wartość książki, gdyż uwypukla liczne mankamenty w obrębie petrażycjańskiego systemu teoretyczno-metodologicznego. Zebranie, selekcja, kompilacja prezentowanego tu materiału wymagały, jak mniemam, nakładów benedyktyńskiej pracy. Bardzo to doceniam, jednak żałuję, iż sam autor nie pokusił się o zbudowanie własnego (autorskiego) stanowiska krytycznego i dobitnie go nie wyeksponował. Nie chodzi oczywiście o narzucenie kierunku refleksji, natomiast byłoby mile widziane, gdyby Dąbrowski wypełnił luki w dotychczas utrwalonych poglądach lub wyznaczył nowy kierunek dyskusji krytycznej. Jestem przekonana, że warto to zrobić, i mam nadzieje, że kiedyś autor napisze krytyczny appendix, który podsumuje ten rozdział.

I wreszcie, w ostatnim, piątym, rozdziale Dąbrowski objaśnia genezę i istotę przeżyć etycznych oraz norm prawnych i moralnych - z wyraźnym zastrzeżeniem, iż nie będzie zajmował się „całokształtem zagadnień związanych z prawem i moralnością, lecz jedynie ich aspektami, które wynikają bezpośrednio z teorii 
emocji Petrażyckiego" (Dąbrowski, 2019: 210). Mamy więc do czynienia z celowym zawężeniem spektrum rozważań do teorii impulsji. Pomimo narzuconych ograniczeń rozdział jest merytorycznie wysycony, mieści w sobie mnóstwo faktów i odniesień, które doskonale obrazują strukturę przeżycia emocjonalnego, system aksjonormatywny, znaczenie norm, podział mechanizmów motywacyjnych. Swoistym podsumowaniem podejmowanych rozważań jest „dyskusja wokół Petrażyckiego koncepcji moralności i prawa” (Dąbrowski, 2019: 225-235), gdzie autor przytacza liczne publikacje, w których przewija się wątek petrażycjańskiej teorii (niekiedy się z nimi zgadza, niekiedy polemizuje). Sporo tu odwołań do socjologii i antropologii, co w efekcie powoduje, iż wywód schodzi z poziomu meta- i dotyka życia społecznego, kultury oraz struktury danej społeczności lub społeczeństwa. Moim zdaniem uwzględnienie refleksji Bronisława Malinowskiego i Marii Ossowskiej jest znakomitym pomysłem — przede wszystkim dlatego, iż unaocznia rangę i rolę norm społecznych oraz reguł kulturowych jako podstawowych czynników prawotwórczych.

Monografię Dąbrowskiego uważam za wartościową, potrzebną, pożyteczną. Odznacza się ona wieloma przymiotami, które potwierdzają jej wysoką jakość oraz przydatność w dyskusjach naukowych i publicystycznych. Dużym atutem recenzowanej pozycji jest jasność wypowiedzi - treści są prezentowane w zrozumiały i klarowny sposób, bez nadmiernego akademickiego zadęcia, które czasem towarzyszy filozoficznym dysputom. To zaś powoduje, iż potencjalnym odbiorcą książki może być zarówno wysoko wykwalifikowane grono naukowe, jak i niespecjaliści, których interesuje złożony świat emocji, uczuć, afektów. Książka została napisana potoczystym stylem, bardzo dobrą i płynną polszczyzną. Wywód jest przemyślany, oparty na bogatej, wielodziedzinowej literaturze podmiotu i przedmiotu, wzbogacony mocno rozbudowanym systemem przypisów dolnych, które same w sobie dostarczają wielu rzeczowych i absorbujących informacji - metaforycznie mówiąc, didaskalia są równie interesujące, co sama sztuka. Narracja jest prowadzona starannie, rozważnie i przejrzyście, z zachowaniem zasad argumentacji oraz ciągów przyczynowo-skutkowych. Dostrzegam w tym zamyst i plan - poszczególne rozdziały wynikają z siebie bądź stanowią wzajemne dopełnienie, nie są ani przegadane, ani zbyt lakoniczne. Krótko mówiąc, Dąbrowski napisał tę książkę tak, jak trzeba - po jej lekturze nie mam poczucia niedosytu, niekompletności, pobieżnego ujęcia niektórych wątków. Monografia jest inspirująca poznawczo, a równocześnie staje się świetnym materiałem dydaktycznym, bowiem w przejrzysty i przystępny sposób objaśnia zawiłe teorie. Pomimo kilku zgłoszonych wcześniej uwag trudno mi doszukać się w tekście jakichkolwiek uchybień, błędów lub wpadek wydawniczo-edytorskich. Nawet przy pobieżnej lekturze widać gruntowne przygotowanie autora do napisania tej książki oraz szeroki warsztat badawczy. Nie mam najmniejszych wątpliwości, iż ta monografia była potrzebna, gdyż: stanowi cenny punkt odniesienia dla dalszych refleksji naukowych ukierunkowanych na 
zrozumienie oraz wyjaśnienie emocji; może wywrzeć znaczący wpływ na rozwój pokrewnych badań nie tylko z zakresu filozofii, lecz także prawa, historii, psychologii, socjologii; wzbogaca bibliografię na temat Petrażyckiego, utrwalając jego spuściznę.

Stefan Rozmaryn kiedyś powiedział: „można się z Leonem Petrażyckim nie zgadzać - można i trzeba oceniać jego poglądy krytycznie, ale pomijać ich nie można i nie wolno" (Rozmaryn, 1969: 7). Wziąwszy pod uwagę to stwierdzenie, Andrzej Dąbrowski, wydając swoją książkę, zrealizował ambitną naukową misję.

\section{BIBLIOGRAFIA}

Augustyn. (1977). O państwie Bożym. Przeciw poganom ksiąg XII. (Przeł. W. Kornatowski). Warszawa: Instytut Wydawniczy Pax.

Damasio, A.R. (2011). Błąd Kartezjusza. Emocje, rozum i ludzki mózg. (Przeł. M. Karpiński). Poznań: Rebis.

Dąbrowski, A. (2019). Źródła, natura i funkcje emocji. Studium teorii impulsji Leona Petrażyckiego w kontekście wspótczesnych badań. Warszawa: Wydawnictwa Uniwersytetu Warszawskiego.

Ekman, P. \& Davidson, R.J. (2012). Natura emocji. (Przeł. B. Wojciszke). Sopot: Gdańskie Wydawnictwo Psychologiczne.

Fonberg, E. (1979). Nerwice a emocje. Fizjologiczne mechanizmy. Wrocław: Ossolineum.

Kik, M. (2006). Leona Petrażyckiego filozofia prawa. Czasopismo Filozoficzne, 1, 52-61.

Kojder, A. (2018). Idee naukowe Leona Petrażyckiego, które przetrwały próbę czasu. Studia Iuridica, 74, 155-161.

Markowski, J. (2018). Leon Petrażycki — „ordynarnyj” profesor. Miscellanea Historico-Iuridica, 17, 121-141.

Rozmaryn, S. (1969). Przedmowa (s. 6-8). W: K. Opałek (Red.). Z zagadnień teorii prawa i teorii nauki Leona Petrażyckiego. Warszawa: Państwowe Wydawnictwo Naukowe.

Reykowski, J. (1968). Eksperymentalna psychologia emocji. Warszawa: Książka i Wiedza. 
